\title{
STRUKTUR KOMUNITAS HYMENOPTERA PARASITOID PADA TUMBUHAN LIAR DI SEKITAR PERTANAMAN PADI DI DAERAH ALIRAN SUNGAI (DAS) CIANJUR, JAWA BARAT
}

\author{
Yaherwandi $^{1}$, S. Manuwoto ${ }^{2}$, D. Buchori ${ }^{2}$ P. Hidayat $^{2}$ dan L.B. Prasetyo $^{3}$
}

\begin{abstract}
Hymenoptera Parasitoid Community Structure on Non-crops Vegetation Around Rice fields in Cianjur Watershed, West Java. Hymenoptera parasitoids have an important role in agroecosystem because of their ability in suppressing pest population. Their presence in the field is seen as the key to agricultural ecosystem. Their presence can be influenced by the availability of non-crop vegetation. Some adult Hymenoptera parasitoids require food in the form of pollen and nectar of wild flowers to ensure effective reproduction and longevity. The objective of this research was to study Hymenoptera parasitoid communities in non-crop vegetation around rice fields at Cianjur Watershed. Samplings were conducted at three different landscape, i.e. Nyalindung, Gasol and Selajambe West Java. Insects were sampled by two trapping techniques (farmcop and sweep net) in two lines of transect for each landscape. A total of 257 species from 25 families of Hymenoptera parasitoids were collected in non-crop vegetation at Cianjur Watershed. Landscape structure, flowering vegetation, and pesticide application affected the species richness, diversity and evenness of Hymenoptera parasitoid in noncrop vegetation.
\end{abstract}

Key words : hymenoptera, parasitoid, non-crops vegetation, rice fields

\section{PENDAHULUAN}

Struktur komunitas merupakan suatu konsep yang mempelajari susunan atau komposisi spesies dan kelimpahannya dalam suatu komunitas. Secara umun ada tiga pendekatan yang dapat digunakan untuk mengambarkan struktur komunitas yaitu keanekaragaman spesies, interaksi spesies, dan organisasi fungsional (Schowalter, 1996). Masingmasing pendekatan memberikan informasi yang sangat berguna. Pemilihan pendekatan yang akan digunakan tergantung kepada tujuan dan pertimbangan praktisnya. Pendekatan yang digunakan untuk mempelajari struktur komunitas Hymenoptera parasitoid dalam penelitian ini adalah keanekaragaman spesies.

Keanekaragaman spesies adalah keanekaan jenis organisme yang menempati suatu ekosistem baik di darat maupun di lautan (Primack, 1998). Keanekaragaman spesies merupakan salah satu tema utama dalam penenelitian ekologi. Banyak penelitian telah dilakukan untuk mempelajari pengaruh perubahan kondisi lingkungan terhadap keanekaragaman spesies dan sebaliknya bagaimana keanekaragaman spesies mempengaruhi stabilitas komunitas alami (Schowalter, 1996).
Keanekaragaman dan kelimpahan spesies parasitoid pada skala spasial yang lebih luas (lanskap) dipengaruhi oleh struktur fisik sistem produksi pertanian (Marino \& Landis, 1996). Keanekaragaman dan parasitisme parasitoid dari ulat grayak Pseudaletia unipuncta Haworth (Lepidoptera: Noctuidae) lebih tinggi pada pertanaman jagung dengan struktur lanskap yang komplek (polikultur) daripada pertanaman jagung dengan struktur lanskap yang sederhana (monokultur) (Marino \& Landis, 1996). Selanjutnya dilaporkan keanekaragaman parasitoid dari ulat grayak $P$. unipuncta lebih tinggi di pinggir pertanaman jagung yang berdekatan dengan habitat tumbuhan liar daripada di tengah pertanaman jagung (Menalled et al., 1999).

Tumbuhan liar yang tumbuh di sekitar pertanaman tidak hanya berfungsi sebagai tempat berlindung (shelter) dan pengungsian musuh alami ketika kondisi lingkungan tidak sesuai (van Emden, 1991), tetapi juga menyediakan inang alternatif dan makanan tambahan bagi imago parasitoid seperti tepung sari dan nektar dari tumbuhan berbunga serta embun madu yang dihasilkan oleh ordo Homoptera (Altieri \& Nicholls, 2004). Nektar yang kaya karbohidrat sebagai sumber energi dan tepung sari yang seringkali diperoleh bersamaan dengan nektar menyediakan nutrisi untuk produksi telur beberapa

\footnotetext{
${ }^{1}$ Departemen Hama dan Penyakit Tumbuhan, Fakultas Pertanian, Universitas Andalas

${ }^{2}$ Departemen Proteksi Tanaman, Fakultas Pertanian, Instiut Pertanian Bogor

${ }^{3}$ Departemen Konservasi Sumberdaya Hutan, Fakultas Kehutanan, Instiut Pertanian Bogor
} 
spesies parasitoid (Wratten et al., 2004). Banyak penelitian yang memperlihatkan bahwa manipulasi tumbuhan liar dapat meningkatkan kelimpahan dan keanekaragaman musuh alami, termasuk Hymenoptera parasitoid (Landis et al., 2000 ; Altieri \& Nicholls, 2004).

Tumbuhan liar di lanskap pertanian di Daerah Aliran Sungai (DAS) Cianjur umumnya tumbuh di pematang sawah, tepian saluran irigasi, lahan bera, talun dan kebun campur. Tumbuhan liar yang tumbuh di sekitar pertanaman padi memberikan keuntungan dalam konservasi parasitoid. Sayangnya, masih banyak petani beranggapan bahwa tumbuhan liar yang tumbuh di sekitar pertanaman padi sebagai sumber hama dan penyakit, sehingga tidak sedikit pematang sawah dan pinggiran saluran irigasi dibersihkan dari tumbuhan liar pada saat awal musim tanam. Oleh karena itu penelitian tentang struktur komunitas Hymenoptera parasitoid pada tumbuhan liar yang tumbuh di sekitar pertanaman padi perlu dilakukan. Penelitian bertujuan untuk mempelajari struktur komunitas Hymenoptera parasitoid pada tumbuhan liar di sekitar pertanaman padi pada berbagai struktur lanskap pertanian dan menganalisis kemiripan komunitas Hymenoptera parasitoid pada habitat tumbuhan liar dengan pertanaman padi dan sayuran.

\section{METODE PENELITIAN}

Lokasi penelitian. Penelitian ini dilakukan di tiga desa yaitu desa Nyalindung (bagian hulu), Gasol (bagian tengah) dan Selajambe (bagian hilir) DAS Cianjur. Masing-masing desa mempunyai struktur lanskap atau jenis penggunaan lahan yang berbeda. Diskripsi masing-masing lanskap tersebut disajikan pada Tabel 1. Penelitian dilaksanakan dari bulan Juni 2003 sampai September 2004.

Pengambilan sampel Hymenoptera parasitoid pada tumbuhan liar. Sampel Hymenoptera parasitoid diambil dari tumbuhan liar yang terdapat pada pematang sawah, tepian saluran irigasi, lahan bera, talun dan kebun campur. Pengambilan sampel ini dilakukan pada saat tanaman padi berumur 20, 50, 80 hari setelah tanam (hst) dan satu minggu setelah panen. Penentuan titik sampel pada masing-masing lanskap dengan cara menentukan dua jalur transek dengan panjang lebih kurang $1000 \mathrm{~m}$ atau sepanjang pertanaman yang ada dan jarak antara transek 500 $600 \mathrm{~m}$. Sepanjang jalur transek ditentukan titik pengambilan sampel yang berjarak $100 \mathrm{~m}$, sehingga masing-masing transek terdapat 10 titik sampel (20 titik sampel setiap lanskap).

Pengambilan sampel serangga pada setiap titik sampel pada jalur transek dilakukan dengan menggunakan mesin penghisap serangga farmcop, dan jaring ayun (sweep net). (Heong et al., 1991). Pengambilan sampel pada pematang sawah dan pinggiran saluran irigasi yang dihisap dengan farmcop terlebih dahulu disungkup dengan kurungan kain kasa berbingkai, kemudian dihisap dengan farmcop selama lima menit untuk setiap titik sampel (Heong et al., 1991). Pengambilan sampel serangga dengan jaring ayun pada setiap titik sampel dilakukan dengan 10 kali ayunan ganda sambil berjalan. Serangga yang tertangkap dengan farmcop dan jaring ayun dibersihkan dari kotoran dan disimpan dalam tabung film berisi alkohol 70\% untuk diidentifikasi di laboratorium.

Identifikasi serangga dilakukan di

Tabel 1. Deskripsi lokasi penelitian di Daerah Aliran Sungai Cianjur

\begin{tabular}{|c|c|c|c|}
\hline Desa /Lanskap & Koordinat/lokasi & Ketinggian & Tipe penggunaan lahan \\
\hline Nyalindung & $\begin{array}{l}06^{\circ} 47^{\prime} 22,7^{\prime \prime} \text { LS } \\
107^{\circ} 03^{\prime} 30,6^{\prime} \text { BT }\end{array}$ & $879-1010$ m.dpl & $\begin{array}{l}\text { padi polikultur, palawija, sayuran, kampung } \\
\text { dan kebun campur }\end{array}$ \\
\hline Gasol & $\begin{array}{l}06^{\circ} 48^{\prime} 17,0^{\prime \prime} \text { LS } \\
107^{\circ} 05^{\prime} 40,1^{\prime} \text { BT }\end{array}$ & 665 - 693 m.dpl & $\begin{array}{l}\text { padi monokultur, sedikit palawija dan } \\
\text { sayuran, kampung dan kebun campur }\end{array}$ \\
\hline Selajambe & $\begin{array}{l}06^{\circ} 48^{\prime} 09.0^{\prime \prime} \text { LS } \\
107^{\circ} 12^{\prime} 52,9^{\prime} \text { BT }\end{array}$ & $346-351$ & $\begin{array}{l}\text { padi monokultur, kampung dan kebun } \\
\text { campur }\end{array}$ \\
\hline
\end{tabular}

LS (lintang selatan), BT (bujur timur), m.dpl (meter di atas permukaan laut) 
Laboratorium Bioekologi Parasitoid dan Predator, Departemen Proteksi Tanaman, Fakultas Pertanian, Institut Pertanian Bogor. Semua serangga yang diperoleh dipisahkan berdasarkan ordonya. Khusus untuk ordo Hymenoptera parasitoid identifikasi dilanjutkan sampai tingkat famili dan morfospesies (hanya diberi kode). Morfospesies dalam tulisan ini selanjutnya disebut spesies saja. Identifikasi serangga untuk tingkat famili menggunakan acuan buku Goulet dan Huber (1993).

Pengambilan sampel Hymenoptera parasitoid pada pertanaman padi dan sayuran. Pengambilan sampel pada pertanaman padi dan sayuran dilakukan saat tanaman padi berumur 20, 50, 80 hari setelah tanam (hst) dan satu minggu setelah panen. Penentuan titik sampel dan metode pengambilan sampel sama dengan yang dilakukan pada tumbuhan liar.

\section{Pengambilan sampel tumbuhan liar.} Pengambilan sampel tumbuhan liar dilakukan pada pematang sawah, pinggiran saluran irigasi, lahan bera, talun, dan kebun campuran. Penentuan titik sampel sama dengan pengambilan sampel Hymenoptera parasitoid, tetapi jarak titik sampel sepanjang jalur transek $200 \mathrm{~m}$, sehingga tiap lokasi ada 10 titik sampel. Pengambilan sampel tumbuhan liar menggunakan metode kuadrat dengan ukuran petak sampel $1 \mathrm{~m}^{2}$. Semua tumbuhan liar dalam kuadrat dihitung jenis dan jumlah individunya. Setiap jenis tumbuhan diambil sampelnya untuk diidentifikasi di laboratorium.

Indentifikasi tumbuhan liar dilakukan di Laboratorium Bioekologi Parasitoid dan Predator Departemen Hama dan Penyakit Tumbuhan Fakultas Pertanian, Institut Pertanian Bogor. Identifikasi tumbuah liar mengunakan acuan buku Kosterman, Wirjahardja dan Dekker (1987) dan Laumonier, Megia \& Veenstra (1987).

Analisis data. Data Hymenoptera parasitoid yang diperoleh dianalisis untuk menentukan kekayaan spesies, indeks keanekaragaman Shannon-Wienner dan indeks kemerataan Simpson's (Magurran, 1988; Krebs, 1999). Masing-masing indeks tersebut disajikan dalam persamaan sebagai berikut :

Kekayaan spesies (s) = total jumlah spesies yang diperoleh

$$
\begin{array}{ll}
\text { Indeks Shannon-Wiener (H') } & =-\sum p_{i} \log _{e} p_{i} \\
\text { Indeks kemerataan Simpson's }\left(\mathrm{E}_{1 / \mathrm{D})}\right) & =\frac{1 / D}{S}
\end{array}
$$

dengan:

$\mathrm{p}_{\mathrm{i}}$

$1 / \mathrm{D}$

$\mathrm{S}$

$=$ proporsi spesies ke-i terhadap total jumlah spesies

$=$ indeks keanekaragaman Simpson's

$=$ total jumlah spesies yang diperoleh

Untuk menghitung kekayaan spesies, indeks Shannon-Wiener dan indeks kemerataan Simpson's digunakan program Ecological Methodology 2nd edition (Krebs, 1999). Untuk menentukan perbedaan kekayaan, keanekaragaman dan kemerataan spesies Hymeneoptera parasitoid digunakan analisis ragam (One way ANOVA) dan uji jarak berganda Duncan (DNMRT) 95\% menggunakan program Statistica for Windows 5.0.

Untuk membuat kurva akumulasi spesies, jumlah spesies yang diperoleh pada setiap titik sampel diacak sebanyak 50 kali dengan program EstimateS 6.0b1. Dari hasil pengacakan itu diperoleh data estimasi kekayaan spesies Hymenoptera parasitoid berdasarkan Jackknife-1 Estimator.

Analisis kemiripan komunitas Hymenoptera parasitoid pada tumbuhan liar, tanaman padi dan sayuran dilakukan dengan menentukan indeks kemiripan Sorensen. Untuk memperoleh nilai indeks Sorensen digunakan program Biodiv97 yang diintegrasikan dalam Microsoft Exel.

Analisis vegetasi dilakukan dengan menentukan kerapatan, frekuensi dan indeks nilai pentingnya (Setiadi et al. 1989). Untuk menghitung ketiga nilai tersebut digunakan persamaan berikut:

$\mathrm{KM}(\mathrm{i})=\underline{\mathrm{Jml} \text {. Individu suatu jenis } \mathrm{i}}$ Jml. Total luas area petak sampel

$\mathrm{KR}(\mathrm{i})=\underline{\text { Kerapatan mutlak jenis } \mathrm{i}}$ Kerapatan total seluruh jenis

$\mathrm{FM}(\mathrm{i})=\underline{\mathrm{Jml}}$. Satuan petak sampel yang diduduki jeni i Jml. Petak sampel yang dibuat dalam analisis

$F R(i)=$ Frekuensi mutlak jenis $\mathrm{i}$ Frekuensi total seluruh jenis 
$\operatorname{INP}(\mathrm{i})=\mathrm{KR}(\mathrm{i})+\mathrm{FR}(\mathrm{i})$

\author{
dengan : \\ $\mathrm{KM}=$ Kerapatan Mutlak \\ $\mathrm{KR}=$ Kerapatan Relatif \\ FM = Frekuensi Mutlak \\ $\mathrm{FR}=$ Frekuensi Relatif \\ INP = Indeks Nilai Penting
}

\section{HASIL DAN PEMBAHASAN}

Komunitas tumbuhan liar di sekitar pertanaman padi. Sebanyak 34 famili tumbuhan liar telah dikoleksi di ketiga lanskap. Pada lanskap Nyalindung diperoleh 42 spesies dan 22 famili, Gasol 51 spesies dan 22 famili dan Selajambe 45 spesies dan 22 famili (Tabel 2) Dari hasil analisis vegetasi diperoleh dua famili tumbuhan liar yang mendominasi ketiga lanskap tersebut yaitu famili Asteraceae dengan INP > 50\% dan famili Poaceae dengan INP > 39\% (Tabel 2). Hasil yang mirip juga sebelumnya ditemukan oleh Suana (2004) pada ketiga lanskap tersebut.

Jenis tumbuhan liar yang mempunyai nilai INP $>10 \%$ di lanskap Nyalindung yaitu Ageratum conyzoides L., Calinsoga parviflora Cov. dan Spilanthes paniculata Wall.ex. DC dari famili Asteraceae dan Eleusine indica (L.) Gaertn dari famili Poaceae. Di lanskap Gasol yaitu A. conyzoides L. dari famili Asteraceae dan Digitaria sp. dari famili Poaceae. Di lanskap Selajambe yaitu $A$. conyzoides L. dan Sphaeranthus africanus L. dari famili Asteraceae dan Digitaria sp. dari famili Poaceae. Dari hasil penelitian ini terlihat bahwa jenis tumbuhan liar yang mendominasi ketiga lanskap pertanian di DAS Cianjur adalah dari famili Asteraceae. Nentwig (1998) melaporkan bahwa tumbuhan liar berbunga seperti famili Asteraceae dan Brassicaceae berperan penting dalam meningkatkan kelimpahan Hymenoptera parasitoid terutama famili Braconidae, Ichneumonidae, Proctotrupidae, Pteromalidae, Torymidae dan Mymaridae pada habitat tumbuhan liar.

Kelimpahan Hymenoptera parasitoid pada habitat tumbuhan liar. Hasil penelitian ini menunjukkan bahwa habitat tumbuhan liar di sekitar pertanaman padi mempunyai kekayaan spesies Hymenoptera parasitoid yang cukup tinggi. Jumlah keseluruhan
Hymenoptera parasitoid yang telah dikoleksi pada ketiga lanskap adalah 257 spesies dan 25 famili (Tabel 2). Hasil ini relatif lebih tinggi dari yang ditemukan oleh Nentwig (1998) dan Herlinda et al. (2000), yaitu berturut-turut 17 famili dan delapan famili.

Famili Hymenoptera parasitoid yang dominan ditemukan di Lanskap Nyalindung adalah Braconidae, Encyrtidae, Eulophiodae dan Scelionidae, di lanskap Gasol adalah Braconidae, Eulophiodae, Ichneumonidae dan Scelionidae, sedangkan di lanskap Selajambe adalah Braconidae, Encyrtidae, Eulophiodae, Eurytomidae dan Scelionidae (Gambar 1). Dari hasil tersebut terlihat bahwa Braconidae dan Scelionidae merupakan famili Hymenoptera parasitoid yang mendominasi habitat tumbuhan liar pada ketiga lanskap.

Estimasi jumlah spesies Hymenopetra parasitoid pada habitat tumbuhan liar. Seiring dengan pertambahan jumlah titik sampel kurva akumulasi spesies Hymenoptera parasitoid pada ketiga lanskap terlihat masih ada peningkatan, tetapi tidak terlalu tajam (Gambar 2). Jumlah spesies yang dikoleksi pada lanskap Nyalindung, Gasol dan Selajambe berturutturut adalah 161, 121 dan 153 (Gambar 2). Sedangkan hasil estimasi dengan Jackknife-1 estimator berturutturut adalah 223, 173 dan 149 spesies untuk Nyalindung, Gasol dan Selajambe (Gambar 1). Dari hasil penelitian ini terlihat bahwa 70\% spesies Hymenoptera parasitoid telah dikoleksi. Hal ini menunjukkan bahwa kekayaan spesies yang dikoleksi belum optimal. Banyak ahli ekologi yang tidak setuju dengan Jackknife estimator diantaranya adalah Heltshe dan Forrester (1983b dalam Krebs, 1999) karena estimasi kekayaan spesies dalam komunitas oleh Jackknife estimator cenderung bias positif atau lebih tinggi (overestimate). Tetapi, Palmer (1990 dalam Krebs, 1999) menemukan bahwa Jackknife estimator lebih akurat dari delapan estimator lain yang digunakan.

Jackknife estimator dipengaruhi oleh jumlah spesies total, ukuran sampel dan jumlah spesies unik (rare spesies) (Krebs, 1999). Dengan demikian, kemungkinan peralatan yang dipakai untuk koleksi serangga dalam penelitian ini merupakan salah satu penyebab tidak optimalnya jumlah spesies yang dikoleksi. Jaring ayun dan farmcop merupakan alat yang harganya relatif murah dan sangat mudah untuk 
Tabel 2. Famili, jumlah spesies, Kerapatan Relatif (KR), Frekuensi Relatif (FR) dan Indeks Nilai Penting (INP) tumbuhan liar di lanskap Nyalindung, Gasol dan Selajambe

\begin{tabular}{|c|c|c|c|c|c|c|c|c|c|c|c|c|}
\hline \multirow[b]{2}{*}{ Famili } & \multicolumn{4}{|c|}{ Nyalindung } & \multicolumn{4}{|c|}{ Gasol } & \multicolumn{4}{|c|}{ Selajambe } \\
\hline & $\begin{array}{c}\text { Jum. } \\
\text { sp }\end{array}$ & $\begin{array}{l}\text { KR } \\
(\%)\end{array}$ & $\begin{array}{c}\text { FR } \\
(\%)\end{array}$ & $\begin{array}{l}\text { INP } \\
(\%)\end{array}$ & $\begin{array}{c}\text { Jum. } \\
\text { sp }\end{array}$ & $\begin{array}{l}\text { KR } \\
(\%)\end{array}$ & $\begin{array}{l}\text { FR } \\
(\%)\end{array}$ & $\begin{array}{l}\text { INP } \\
\text { (\%) }\end{array}$ & $\begin{array}{c}\text { Jum. } \\
\text { sp }\end{array}$ & $\begin{array}{l}\text { KR } \\
(\%)\end{array}$ & $\begin{array}{l}\text { FR } \\
(\%)\end{array}$ & $\begin{array}{l}\text { INP } \\
(\%)\end{array}$ \\
\hline Asteraceae & 8 & 36,17 & 28,32 & 64,42 & 10 & 36,06 & 25,6 & 61,65 & 9 & 28,32 & 25,78 & 54,09 \\
\hline Portulacaceae & 1 & 2,82 & 3,33 & 6,16 & 1 & 0,88 & 1,55 & 2,43 & 1 & 0,66 & 0,78 & 1,44 \\
\hline Commelinaceae & 1 & 2,33 & 5 & 7,33 & 1 & 1,63 & 2,33 & 3,96 & 1 & 2,78 & 3,13 & 5,91 \\
\hline Rubiacea & 2 & 1,22 & 1,66 & 2,9 & 1 & 0,75 & 1,55 & 2,3 & 2 & 7,85 & 6,26 & 14,11 \\
\hline Сурегасеа & 2 & 4,17 & 5,83 & 10,01 & 7 & 7,17 & 7,78 & 14,9 & 5 & 9,32 & 7,02 & 16,36 \\
\hline Poaceae & 9 & 26,74 & 22,5 & 49,25 & 9 & 26,4 & 16,51 & 48,86 & 7 & 20,46 & 18,75 & 39,21 \\
\hline Apiaceae & 1 & 2,95 & 1,67 & 4,61 & 2 & 6,54 & 5,43 & 11,95 & 0 & 0 & 0 & 0 \\
\hline Amaranthaceae & 2 & 5,64 & 5,83 & 11,48 & 2 & 3,14 & 4,66 & 7,79 & 1 & 0,16 & 0,78 & 0,94 \\
\hline Oxalidaceae & 1 & 0,98 & 0,83 & 1,81 & 1 & 2,26 & 0,78 & 3,04 & 1 & 0,33 & 0,78 & 1,11 \\
\hline Brassicaceae & 1 & 2,7 & 5 & 7,7 & 1 & 2,01 & 2,33 & 4,34 & 1 & 0,33 & 1,56 & 1,89 \\
\hline Anagraceae & 1 & 0,12 & 0,83 & 0,96 & 3 & 2,01 & 6,21 & 8,21 & 3 & 4,26 & 4,68 & 8,94 \\
\hline Malvaceae & 1 & 0,36 & 0,83 & 1,2 & 1 & 0,38 & 1,55 & 1,93 & 1 & 1,31 & 2,34 & 3,65 \\
\hline Butomaceae & 1 & 1,1 & 0,83 & 1,94 & 0 & 0 & 0 & 0 & 0 & 0 & 0 & 0 \\
\hline Lamiaceae & 2 & 0,24 & 1,66 & 1,92 & 2 & 0,63 & 2,33 & 2,95 & 2 & 6,06 & 5,47 & 11,52 \\
\hline Acanthaceae & 1 & 0,61 & 0,83 & 1,45 & 1 & 3,02 & 2,33 & 5,24 & & & & \\
\hline Euphorbiaceae & 1 & 0,12 & 0,83 & 0,96 & 3 & 2,39 & 5,43 & 7,81 & 3 & 7,2 & 8,59 & 15,79 \\
\hline Scrophulariaceae & 2 & 0,99 & 1,66 & 2,65 & 0 & 0 & 0 & 0 & 0 & 0 & 0 & 0 \\
\hline Verbenaceae & 1 & 0,37 & 0,83 & 1,2 & 0 & 0 & 0 & 0 & 0 & 0 & 0 & 0 \\
\hline Melastomataceae & 0 & 0 & 0 & 0 & 1 & 0,13 & 0,78 & 0,9 & & 0 & 0 & 0 \\
\hline Araceae & 0 & 0 & 0 & 0 & 1 & 0,13 & 0,78 & 0,9 & & 0 & 0 & 0 \\
\hline Leguminoseae & 0 & 0 & 0 & 0 & 0 & 0 & 0 & 0 & 2 & 1,47 & 3,91 & 5,37 \\
\hline Boraginaceae & 0 & 0 & 0 & 0 & 0 & 0 & 0 & 0 & 1 & 1,8 & 1,56 & 3,36 \\
\hline Polygonaceae & 0 & 0 & 0 & 0 & 0 & 0 & 0 & 0 & 1 & 1,96 & 2,34 & 4,31 \\
\hline Capparidaceae & 0 & 0 & 0 & 0 & 0 & 0 & 0 & 0 & 1 & 0,98 & 1,56 & 2,54 \\
\hline Marsileaceae & 0 & 0 & 0 & 0 & 0 & 0 & 0 & 0 & 1 & 3,76 & 1,56 & 5,33 \\
\hline Solanaceae & 0 & 0 & 0 & 0 & 0 & 0 & 0 & 0 & 1 & 0,16 & 0,78 & 0,94 \\
\hline Famili 1 & 1 & 0,74 & 0,83 & 1,57 & 0 & 0 & 0 & 0 & 1 & 0,33 & 0,78 & 1,11 \\
\hline Famili 2 & 1 & 2,7 & 3,33 & 6,03 & 0 & 0 & 0 & 0 & 0 & 0 & 0 & 0 \\
\hline Famili 3 & 1 & 4,54 & 5 & 9,54 & 1 & 2,14 & 1,55 & 3,69 & 0 & 0 & 0 & 0 \\
\hline Famili 4 & 1 & 2,45 & 2,5 & 4,95 & 1 & 0,25 & 0,78 & 1,03 & 1 & 0,33 & 0,78 & 1,11 \\
\hline Famili 5 & 0 & 0 & 0 & 0 & 1 & 0,25 & 1,55 & 1,8 & 0 & 0 & 0 & 0 \\
\hline Famili 6 & 0 & 0 & 0 & 0 & 1 & 0,5 & 0,78 & 1,28 & 0 & 0 & 0 & 0 \\
\hline Famili 7 & 0 & 0 & 0 & 0 & 1 & 1.38 & 1,55 & 2,93 & 0 & 0 & 0 & 0 \\
\hline Falimi 8 & 0 & 0 & 0 & 0 & 0 & 0 & 0 & 0 & 1 & 0,16 & 0,78 & 0,94 \\
\hline
\end{tabular}


Tabel 3. Famili, jumlah spesies, dan kelimpahan relatif Hymenoptera parasitoid pada habitat tumbuhan liar di lanskap Nyalindung, Gasol dan Selajambe

\begin{tabular}{|c|c|c|c|c|c|c|}
\hline \multirow[b]{2}{*}{ Famili } & \multicolumn{2}{|c|}{ Nyalindung } & \multicolumn{2}{|c|}{ Gasol } & \multicolumn{2}{|c|}{ Selajambe } \\
\hline & Jml. sp & $\begin{array}{c}\text { Kelimpahan } \\
\text { relatif (\%) }\end{array}$ & Jml. sp & $\begin{array}{c}\text { Kelimpahan } \\
\text { relatif (\%) }\end{array}$ & Jml. sp & $\begin{array}{c}\text { Kelimpahan } \\
\text { relatif (\%) }\end{array}$ \\
\hline Aphelinidae & 2 & 1,63 & 1 & 1,08 & 1 & 0,29 \\
\hline Bethylidae & 5 & 1,49 & 1 & 0,27 & 1 & 0,29 \\
\hline Braconidae & 23 & 23,77 & 17 & 21,29 & 12 & 9,94 \\
\hline Ceraphronidae & 8 & 2,82 & 2 & 1,08 & 6 & 3,51 \\
\hline Chalcididae & 3 & 0,45 & 2 & 0,81 & 6 & 2,49 \\
\hline Diapriidae & 3 & 0,74 & 3 & 1,08 & 7 & 1,46 \\
\hline Drynidae & 0 & 0,00 & 1 & 0,27 & 2 & 0,29 \\
\hline Elasmidae & 2 & 1,19 & 4 & 2,16 & 6 & 2,78 \\
\hline Encyrtidae & 14 & 9,06 & 11 & 5,12 & 18 & 13,89 \\
\hline Eucharitidae & 0 & 0,00 & 0 & 0,00 & 1 & 0,15 \\
\hline Eucoilidae & 6 & 2,23 & 1 & 0,27 & 2 & 0,29 \\
\hline Eulophidae & 19 & 15,45 & 21 & 14,56 & 26 & 14,77 \\
\hline Eupelmidae & 0 & 0,00 & 1 & 0,27 & 1 & 0,29 \\
\hline Eurytomidae & 5 & 4,16 & 4 & 8,36 & 5 & 10,82 \\
\hline Ichneumonidae & 19 & 6,69 & 12 & 9,16 & 10 & 2,19 \\
\hline Mymaridae & 5 & 4,90 & 6 & 8,63 & 8 & 5,26 \\
\hline Mymarommatidae & 1 & 1,78 & 1 & 1,08 & 0 & 0,00 \\
\hline Perilampidae & 0 & 0,00 & 0 & 0,00 & 1 & 0,29 \\
\hline Platygastridae & 2 & 1,04 & 2 & 2,16 & 3 & 3,36 \\
\hline Pteromalidae & 4 & 5,65 & 4 & 3,50 & 5 & 2,92 \\
\hline Scelionidae & 31 & 10,55 & 20 & 10,51 & 22 & 10,96 \\
\hline Scoliidae & 0 & 0,00 & 0 & 0,00 & 1 & 0,15 \\
\hline Signiphoridae & 1 & 0,15 & 1 & 1,35 & 2 & 4,53 \\
\hline Tetracampidae & 4 & 5,05 & 2 & 4,85 & 3 & 4,68 \\
\hline Tricogrammatidae & 4 & 1,19 & 4 & 2,16 & 4 & 4,39 \\
\hline Total & 161 & 100,00 & 121 & 100,00 & 153 & 100,00 \\
\hline
\end{tabular}




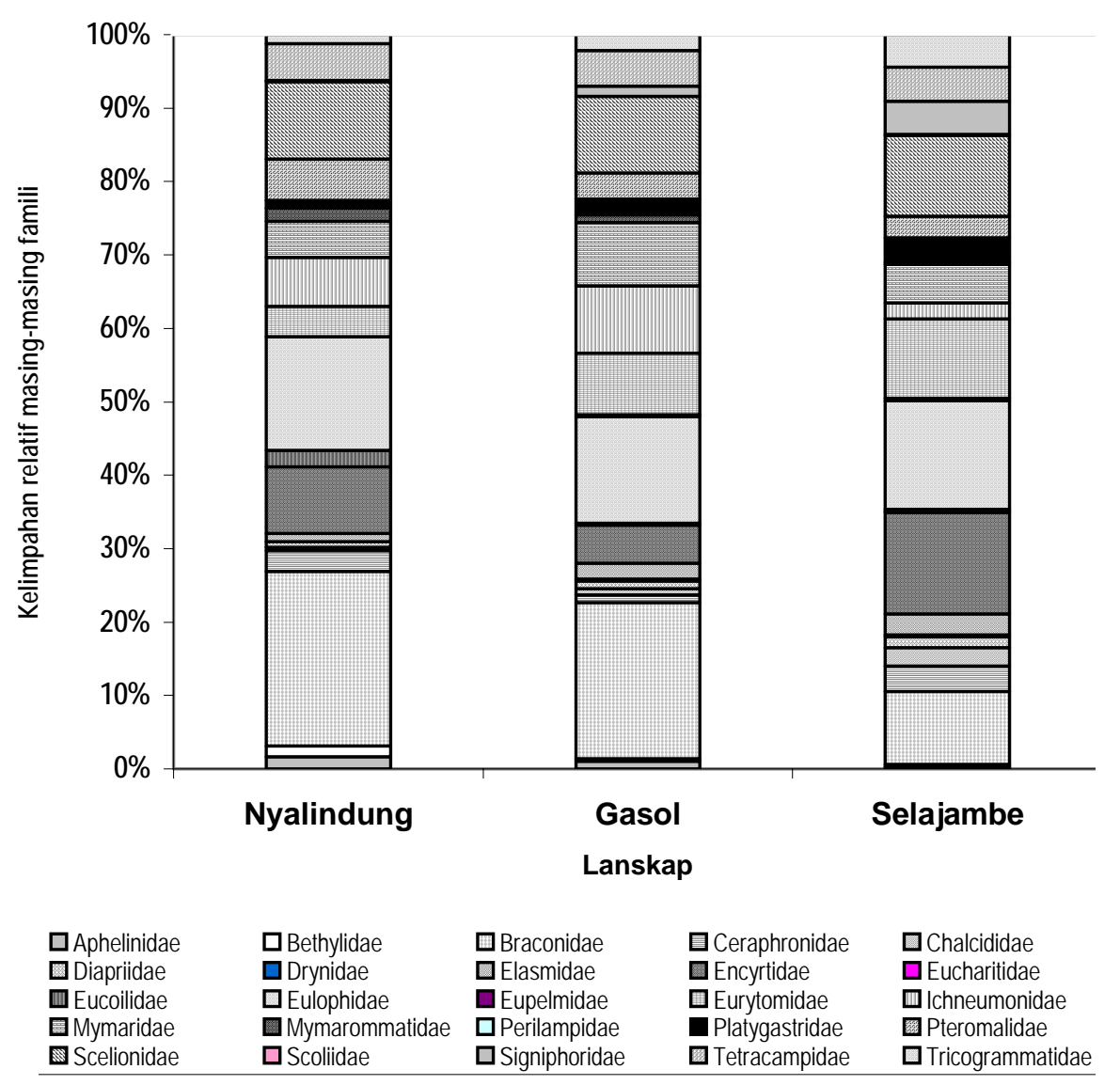

Gambar 1. Kelimpahan relatif masing-masing famili Hymenoptera parasitoid pada tumbuhan liar di ketiga lanskap.
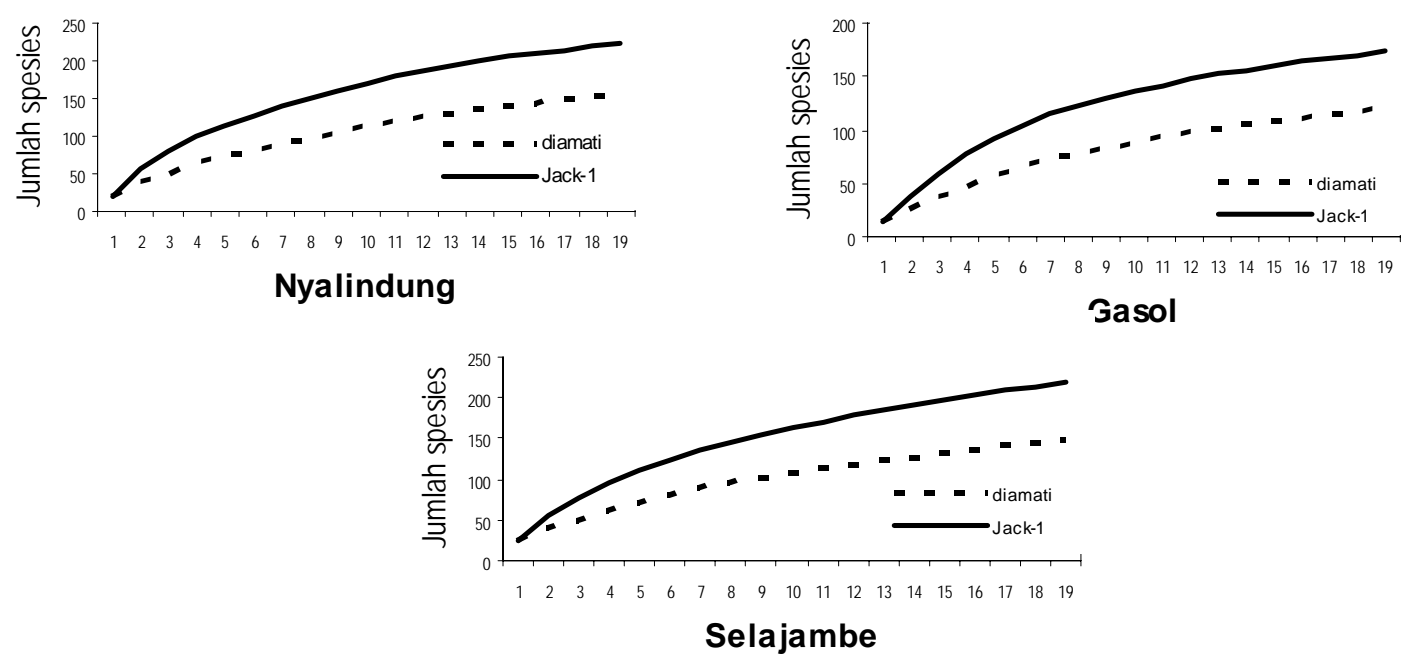

Gambar 2. Kurva akumulasi spesies komunitas Hymenoptera parasitoid pada habitat tumbuhan liar di ketiga lanskap berdasarkan data pengamatan dan Jackknife-1 estimator dengan program EstimateS 6.0b1. 
dibawa, akan tetapi farmcop dan jaring ayun daya hisapnya tidak terlalu kuat dan kurang efektif untuk koleksi serangga yang sangat aktif (Heong et al., 1991).

Kekayaan, keanekaragaman dan kemerataan spesies Hymenoptera parasitoid pada habitat tumbuhan liar. Kekayaan dan keanekaragaman spesies tertinggi terdapat di lanskap Nyalindung dan terendah di lanskap Gasol. Sebaliknya, kemerataan spesies tertinggi terdapat di lanskap Gasol dan terendah di lanskap Nyalindung (Gambar 3). Hasil yang sama juga ditemukan oleh Suana (2004) bahwa keanekaragaman spesies komunitas laba-laba pada habitat tumbuhan liar di lanskap Nyalindung lebih tinggi daripada lanskap Gasol dan Selajambe.

Meskipun, kekayaan spesies dan kelimpahan individu pada lanskap Nyalindung jauh lebih tinggi dari Gasol, tetapi keanekaragamannya tidak berbeda nyata. Hal ini terjadi karena indeks kemerataan spesies pada lanskap Gasol jauh lebih tinggi. Indeks ini mengungkapkan bahwa distribusi kelimpahan spesies di dalam komunitas Hymenoptera parasitoid di lanskap Gasol relatif merata daripada lanskap Nyalindung, sehingga keanekaragaman spesiesnya meningkat. Fenomena yang sama sebelumnya juga dilaporkan Magurran (1998) yang melaporkan bahwa keanekaragaman komunitas burung pada lanskap Wild Wood lebih tinggi daripada Hidden Glen, walaupun kedua habitat mempunyai kekayaan spesies dan kelimpahan individu yang sama, tetapi indek kemerataan spesies di Wild Wood lebih tinggi daripada di Hidden Glen. Dengan demikian, jelas bahwa Indeks Keanekaragaman Shannon dan Wiener (H') dipengaruhi oleh kemerataan spesies dalam komunitas (Magurran, 1988; Krebs, 1999).

Keanekaragaman spesies juga dipengaruhi oleh berbagai faktor lingkungan, diantaranya keanekaragaman spasial, tipe habitat, musim serta kestabilan dan produktivitas lingkungan (Rosenzweig, 1995). Lanskap Nyalindung yang terdiri dari berbagai habitat seperti padi, sayuran (kubis, caisin, wortel, tomat dan lain-lain), palawija dan habitat tumbuhan liar membentuk struktur lanskap yang lebih kompleks daripada lanskap Gasol dan Selajambe. Tingginya keanekaragaman spesies Hymenoptera parasitoid pada

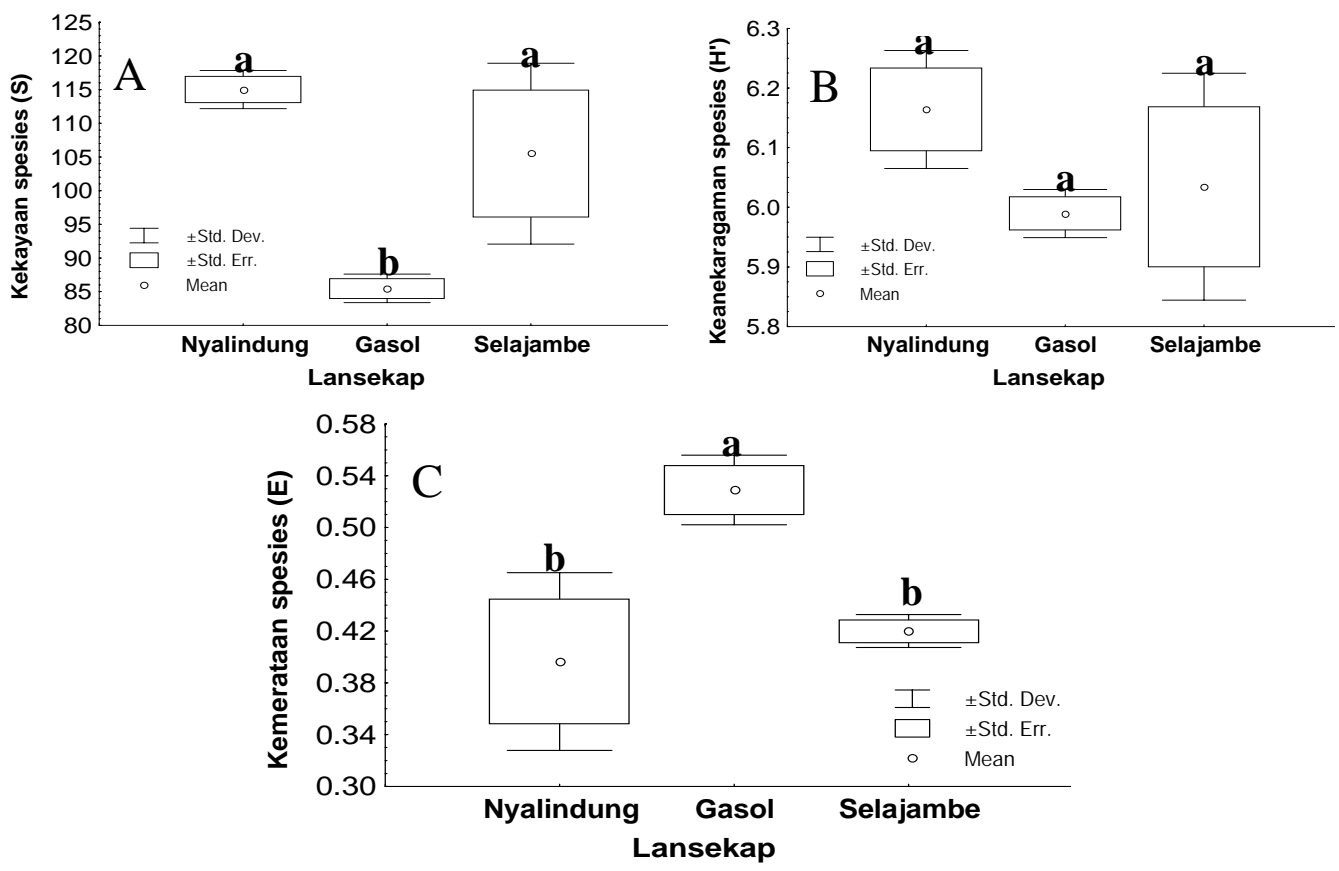

Gambar 3. Kekayaan (A), keanekaragaman (B) dan kemerataan spesies (C) hymenoptera parasitoid pada tumbuhan liar. Huruf berbeda pada gambar yang sama menyatakan perbedaan yang nyata (one-way ANOVA dan DNMRT pada taraf kepercaayaan 95\%). 
Tabel 4. Matrik kemiripan (indeks Sorensen) komunitas Hymenoptera parasitoid antara pertanaman padi dan habitat tumbuhan liar pada ketiga lanskap

\begin{tabular}{lccc}
\hline Lanskap & Habitat & Padi & Tumbuhan liar \\
\hline \multirow{2}{*}{ Nyalindung } & Padi & 1,00 & 1,00 \\
\multirow{2}{*}{ Gasol } & Tumbuhan liar & 0,63 & 1,00 \\
\multirow{2}{*}{ Selajambe } & Padi & 1,00 & 1,00 \\
\hline
\end{tabular}

Tabel 5. Matriks kemiripan (indeks Sorensen) komunitas Hymenoptera parasitoid antara pertanaman padi, sayuran dan habitat tumbuhan liar di lanskap Nyalindung

\begin{tabular}{lccc}
\hline \multicolumn{1}{c}{ Habitat } & Padi & Sayuran & Tumbuhan liar \\
\hline Padi & 1,00 & & \\
Sayuran & 0,58 & 1,00 & \\
Tumbuhan liar & 0,63 & 0,61 & 1,00 \\
\hline
\end{tabular}

habitat tumbuhan liar di lanskap Nyalindung diduga disebabkan oleh struktur lanskapnya yang kompleks. Banyak penelitian yang menunjukkan bahwa struktur lanskap yang kompleks mempunyai keanekaragaman spesies yang tinggi. Marino dan Ladis (1996) misalnya melaporkan keanekaragaman spesies Hymenoptera parasitoid lebih tinggi pada lanskap pertanian yang kompleks ketimbang yang sederhana.

Pada umumnya lahan sawah untuk ketiga lanskap ditanami tanaman semusim yaitu padi dan sayuran. Ekosistem seperti ini biasanya tidak stabil dan selalu mengalami eradikasi saat panen. Kondisi ekosistem yang demikian menyebabkan banyak serangga yang pindah dari pertanaman padi dan sayuran ke habitat tumbuhan liar di pematang sawah, pinggiran saluran irigasi, lahan bera dan kebun campur. Hal ini terlihat pada Tabel 3, kemiripan komunitas Hymenoptera parasitoid antara pertanaman padi dan habitat tumbuhan liar di lanskap Nyalindung, Gasol dan Selajambe berturut-turut 63\%, 60\% dari $61 \%$. Ini menunjukkan bahwa bahwa aliran spesies pada kedua habitat tersebut cukup tinggi.

Pada lanskap Nyalindung, aliran spesies ke habitat tumbuhan liar tidak hanya berasal dari pertanaman padi, tetapi juga dari pertanaman sayuran (Tabel 5). Hal ini terjadi pada saat panen dan tanaman sayuran diperlakukan dengan pestisida untuk pengendalian serangga hama dan penyakit tanaman.
Kondisi lingkungan pertanaman sayuran seperti ini kurang sesuai bagi Hymenoptera parasitoid, sehingga banyak yang mengungsi ke habitat tumbuhan liar untuk berlindung dan bertahan hidup. Faktor-faktor inilah yang menyebabkan keanekaragaman Hymenoptera parasitoid pada habitat tumbuhan liar di lanskap Nyalindung lebih tinggi daripada lanskap lainnya. Habitat tumbuhan liar di pinggir pertanaman dapat berperan sebagai tempat berlindung atau pengungsian musuh alami apabila kondisi pertanaman tidak sesuai seperti ketika tanaman tidak ada (saat panen), pemberaan dan perlakuan pestisida. Sebaliknya habitat tumbuhan liar dapat juga menjadi reservoar musuh alami bagi pertanaman musim berikutnya atau saat pestisida tidak digunakan (van Emden, 1991; Altieri \& Nicholls, 2004).

Keanekaragaman spesies pada habitat tumbuhan liar tidak terlepas dari ketersediaan tumbuhan berbunga yang menyediakan tepung sari dan nektar sebagai makanan tambahan imago Hymenoptera parasitoid pada masing-masing lanskap tersebut. Tingginya keanekaragaman spesies Hymenoptera parasitoid pada laskap Nyalindung diduga disebabkan oleh adanya tumbuhan berbunga seperti Ageratum conyzoides L., Calinsoga parviflora Cov. dan Spilanthes paniculata Wall.ex. DC dari famili Asteraceae yang mendominasi lanskap tersebut. Landis et al. (2000) melaporkan bahwa A. victoriensis 
merupakan komponen penting dalam pengelolaan hama tungau pada pertanaman jeruk di Queensland Australia. Selanjutnya Liang dan Huang (1994 dalam Landis et al., 2000) melaporkan bahw A. conyzoides telah digunakan oleh petani jeruk di Cina untuk mengonservasi musuh alami hama jeruk. Banyak hasil penelitian lain yang melaporkan bahwa ketersedian tumbuhan berbunga pada suatu ekosistem tidak hanya dapat meningkatkan lama hidup dan keperidian parasitoid, tetapi juga meningkatkan keanekaragaman spesies parasitoid (Kartosuwondo, 1994; Wratten et al., 2004).

Selain menyediakan tumbuhan berbunga, habitat tumbuhan liar juga berperan sebagai inang serangga herbivor yang bukan hama (Altieri dan Nicholls, 2004). Serangga herbivor ini biasanya tersedia sebagai inang alternatif Hymenoptera parasitoid. Berkaitan dengan itu, keanekaragaman Hymenoptera parasitoid pada habitat tumbuhan liar juga didukung oleh keberadaan serangga inang alternatif tersebut. Hal ini dapat dilihat pada Gambar 4 yang memperlihatkan kelimpahan Hymenoptera parasitoid berkorelasi positif dengan kelimpahan herbivor. Hal ini berari bahwa keberadaan serangga herbivor sebagai inang alternatif pada habitat tumbuhan liar pada akhirnya akan meningkatkan keanekaragaman Hymenoptera parasitoid pada habitat tersebut.

\section{SIMPULAN}

Sebanyak 34 famili tumbuhan liar telah ditemukan pada ketiga lanskap pertanian di DAS Cianjur. Famili Asteraceae dan Poaceae merupakan famili yang dominan ditemukan pada ketiga lansekap tersebut. Jumlah spesies Hymenoptera parasitoid yang ditemukan pada habitat tumbuhan liar di lanskap DAS Cianjur adalah 257 spesies dalam 25 famili. Jumlah ini telah mencapai $70 \%$ total spesies yang diestimasi dengan Jackknife-1 estimator. Kekayaan dan keanekaragaman spesies pada habitat tumbuhan liar di lanskap Nyalindung lebih tinggi dari lanskap Gasol dan Selajambe, sebaliknya kemerataan spesies di lanskap Nyalindung justru lebih rendah dari lanskap Gasol dan Selajambe. Banyak faktor yang mempengaruhi keanekaragaman, kekayaan dan kemerataan spesies Hymenoptera parasitoid pada habitat tumbuhan liar, diantaranya adalah komposisi habitat yang menyusun masing-masing lanskap, ketersedian tumbuhan berbunga pada masing-masing lanskap dan penggunaan pestisida pada pertanaman sayuran di lanskap Nyalindung. Kemiripan spesies komunitas Hymenoptera parasitoid antara habitat tumbuh liar dengan pertanaman padi dan sayuran lebih dari 60\%. Hal ini berarti habitat tumbuhan liar di lanskap Nyalindung, Gasol dan Selajambe berpotensi digunakan sebagai tempat konservasi Hymenoptera parasitoid.

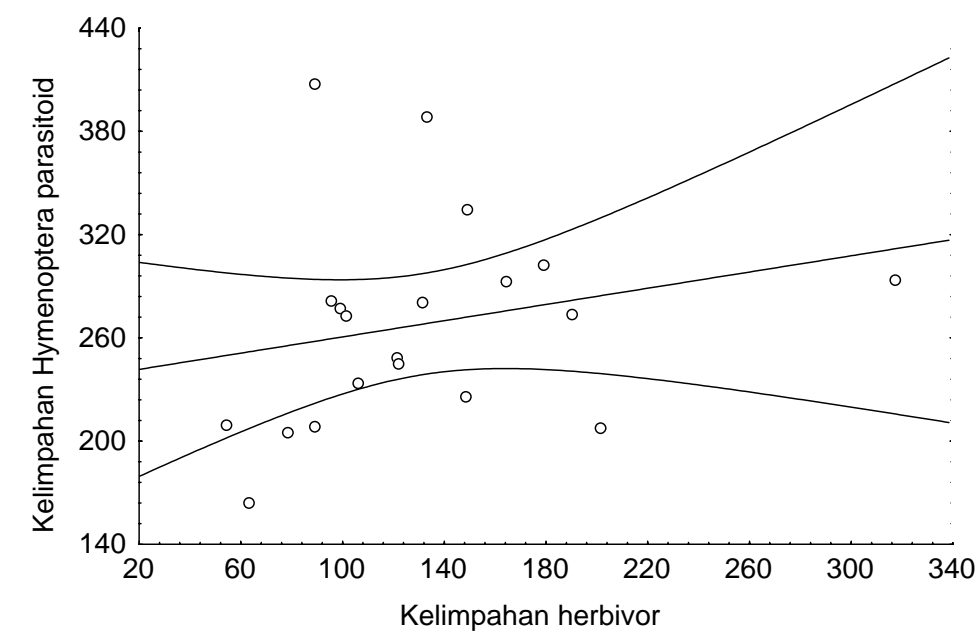

Gambar 4. Hubungan kelimpahan Hymenoptera parasitoid dan Herbivor (Homoptera dan Lepidoptera) pada habitat tumbuhan liar di lanskap pertanian DAS Cianjur. 


\section{DAFTAR PUSTAKA}

Altieri, M.A, \& C.I. Nicholls. 2004. Biodiversity and Pest Management in Agroecosystem. Second Edition. New York: Food Product Press.

Goulet, H, \& J.T. Huber. 1993. Hymenoptera of The world: An Identification Guide to Families. Ottawa: Research Branch Agriculture Canada Publication.

Heong, K.L., G.B. Aquino, \& A.T. Barrion. 1991. Arthropod community structure of rice ecosystem in the Philippines. Bull. of Entomol. Research 81: 407-416.

Herlinda, S., D.S. Kandowangko, I.W. Winasa, \& A. Rauf . 2000. Fauna artropoda penghuni habitat pinggiran di ekosistem persawahan, hlm 163-173. dalam: Keanekaragaman Hayati Artropoda pada Sistem Produksi Pertanian. Prosiding Simposium; Cipayung 16-18 Oktober 2000, Bogor. Perhipunan Entomologi Indonesia dan Yayasan Keanekaragaman Hayati Indonesia.

Kartosuwondo, U. 1994. Populasi Plutella xylostella (L.) (Lepidoptera: Yponomeutidae) dan parasitoid Diadegma semiclausum Hellen (Hymenoptera: Ichneumonidae) pada kubis dan dua jenis Brasicaseae liar. Bull HPT 7: 3949.

Kostermans, A.J.G.H., S. Wirjahardja, \& R.J. Dekker. 1987. The weeds: description, ecology and control, p 24-566. In M Soerjani, A.J.G.H. Kostermans and G. Tjitrosoepomo (eds.), Weed of Rice in Indonesia. Balai Pustaka. Jakarta.

Krebs, C.J. 1999. Ecological Metodology. Second Edition. New York: An imprint of Addison Wesley Longman, Inc.

Landis, D,A., S.D. Wratten, \& G.M. Gurr. 2000. Habitat management to coserve natural enemies of arthropod pests in agriculture. Annu. Rev. Entomol. 45: 175-201.
Laumonier, E.K.W., R. Megia, \& H. Veenstra. 1987. The seedling, $\mathrm{p}$ 567-686. In $\mathrm{M}$. Soerjani, A.J.G.H. Kostermans and G. Tjitrosoepomo (eds.), Weed of Rice in Indonesia. Balai Pustaka. Jakarta.

Magurran, A.E. 1988. Ecological Diversity and Its Measurement. Chapman and Hall. London.

Marino, P.C. \& D.A. Landis. 1996. Effect of landscape structure on parasitoid diversity and parasitism in agroecosystem. Ecological Application 6(1); 276-284.

Menalled, F.D., P.C. Marino, S.H. Gage, \& D.A. Landis. 1999. Does agricultural landscape structure affect parasitism and parasitoid diversity?. Ecological Application 9(2): 634641.

Nentwig, W. 1998. Weedy plant spesies and their beneficial arthropod: potential for manipulation in field crops, p 49-72. In C.H. Pickett \& R.L. Bugg (eds), Enhancing Biological Control. University of Calivornia Press. Los Angeles.

Primack, R.S. 1998. Biologi konservasi. R.S. Primack, J. Supriatna, M. Indrawan \& P. Kramadibrata (penerjemah), A Primer of Conservation Biology. Yayasan Obor Indonesia. Jakarta.

Rosenzweig, M.L. 1995. Species diversity in Space and Time. Cambridge University Press. New York.

Schowalter, T.D. 1996. Insect Ecolohy: An Ecosystem Approach. Academic Press. San Diego.

Setiadi, D., I. Muhadiono, \& A. Yusron. 1989. Penuntun Pratikum Ekologi. Bogor: Institut Pertanian Bogor Press.

Suana, I.W., D. Duryadi, D. Buchori, S. Manuwoto \& H. Triwidodo. 2004. Komunitas laba-laba pada lanskap persawahan di Cianjur. Hayati 11 (4): $145-152$. 
van Emden, H.F. 1991. Plant diversity and natural enemy efficiency in agroecosystems, p 63-80. In M. Mackkauer, L.E.Ehler, \& J. Roland (eds.), Critical Issues in Biological Control. Atheneum Press. Great Britain.
Wratten, S, l. Berndt, J. Tylianakis, P. Ernando \& R. Didham. 2004. Adding flora diversity to enhance parasitoid fitness and efficacy. http://www.bugwood.org/arthropod $\quad[10$ November 2004]. 